\title{
Validation of the generic names Meira and Acaromyces and nineteen species names of basidiomycetous yeasts
}

\section{Cvetomir M. Denchev* \& Teodor T. Denchev}

Institute of Biodiversity and Ecosystem Research, Bulgarian Academy of Sciences, 2 Gagarin St., 1113 Sofia, Bulgaria

Received 19 March 2021 / Accepted 31 March 2021 / Published 3 April 2021

Denchev, C.M. \& Denchev, T.T. 2021. Validation of the generic names Meira and Acaromyces and nineteen species names of basidiomycetous yeasts. - Mycobiota 11: 1-10. doi: 10.12664/mycobiota.2021.11.01

Abstract. Two generic names, Meira and Acaromyces, and nineteen species names of basidiomycetous yeasts, earlier proposed and invalidly published, are validated.

Key words: Acaromyces, basidiomycetous yeasts, Cystobasidium, Farysia, Farysizyma, Glaciozyma, Meira, Microsporomyces, Moniliella, new combination, new genera, new species, nomenclature, Occultifur, Rhodotorula

Taxonomic novelties. New genera: Acaromyces Boekhout, Scorzetti, Gerson \& Sztejnb. ex Denchev \& T. Denchev, Meira Boekhout, Scorzetti, Gerson \& Sztejnb. ex Denchev \& T. Denchev. New species: Acaromyces ingoldii Boekhout, Scorzetti, Gerson \& Sztejnb. ex Denchev \& T. Denchev, Cystobasidium iriomotense Tanimura, Sugita \& M. Takash. ex Denchev \& T. Denchev, Farysia itapuensis Landell \& P. Valente ex Denchev \& T. Denchev, Farysia setubalensis Á. Fonseca \& J. Inácio ex Denchev \& T. Denchev, Farysia taiwaniana P.H. Wang, Yen T. Wang \& S.H. Yang ex Denchev \& T. Denchev, Glaciozyma litoralis Kachalkin ex Denchev \& T. Denchev, Meira geulakonigae Boekhout, Scorzetti, Gerson \& Sztejnb. ex Denchev \& T. Denchev, Meira argovae Boekhout, Scorzetti, Gerson \& Sztejnb. ex Denchev \& T. Denchev, Meira miltonrushii T.A. Rush \& Aime ex Denchev \& T. Denchev, Meira nashicola F. Yasuda \& H. Otani ex Denchev \& T. Denchev, Meira nicotianae H.K. Wang \& F.C. Lin ex Denchev \& T. Denchev, Meira siamensis Limtong, Polburee, Chamnanpa, Khunnamw. \& P. Limtong ex Denchev \& T. Denchev, Microsporomyces hainanensis F.R. Bai \& Yang Liu ex Denchev \& T. Denchev, Moniliella byzovii Thanh, Hien \& T.T. Thom ex Denchev \& T. Denchev, Moniliella sojae Thanh, Hien, Yaguchi, J.P. Samp. \& Lachance ex Denchev \& T. Denchev, Occultifur kilbournensis Kurtzman

\footnotetext{
*Corresponding author: e-mail: cmdenchev@yahoo.co.uk
} 
\& Robnett ex Denchev \& T. Denchev, Occultifur tropicalis Khunnamw., Suruss., Jindam., J.R.A. Ribeiro, Hagler \& Limtong ex Denchev \& T. Denchev, Rhodotorula taiwanensis F.L. Lee \& C.H. Huang ex Denchev \& T. Denchev. New combination: Rhodotorula dairenensis (T. Haseg. \& I. Banno) Denchev \& T. Denchev.

\section{Introduction}

In the cases of description of new yeast species, when the type is a culture preserved in a metabolically inactive state, it is a common practice the type culture to be conserved in two or more collections. Unfortunately, an explicit designation of a holotype often is omitted which has led to description of numerous invalidly published yeast names. In the present article, some invalidly published names of basidiomycetous yeasts are validated.

\section{Validation of the generic names Meira and Acaromyces}

Meira geulakonigii (Boekhout et al. 2003) is not a validly published name, as it was typified with two specimens: CBS 110052 and NRRL Y-27483.

[Meira geulakonigii Boekhout, Scorzetti, Gerson \& Sztejnb., in Boekhout, Theelen, Houbraken, Robert, Scorzetti, Gafni, Gerson \& Sztejnberg, International Journal of Systematic and Evolutionary Microbiology 53: 1661, 2003 (nom. inval., Shenzhen Code, Art. 40.7)]

Meira geulakonigii (Boekhout et al. 2003) is the type species of Meira, making this generic name invalidly published under Art. 40.1, see Arts 6.3, 12.1 (Shenzhen Code). Meira argovae Boekhout et al., M. miltonrushii T.A. Rush \& Aime, M. nashicola F. Yasuda \& H. Otani, M. nicotianae H.K. Wang \& F.C. Lin, and M. siamensis Limtong et al. are not validly published names (Art. 35.1), as they were assigned to an invalidly published generic name.

Meira Boekhout, Scorzetti, Gerson \& Sztejnb. ex Denchev \& T. Denchev, gen. nov. Index Fungorum number: IF 558271

For diagnosis see Boekhout et al., International Journal of Systematic and Evolutionary Microbiology 53: 1660, 2003.

Type species: Meira geulakonigae Boekhout, Scorzetti, Gerson \& Sztejnb. ex Denchev \& T. Denchev

Meira geulakonigae Boekhout, Scorzetti, Gerson \& Sztejnb. ex Denchev \& T. Denchev, sp. nov.

Index Fungorum number: IF 558272 
For description see Boekhout et al., International Journal of Systematic and Evolutionary Microbiology 53: 1661, 2003.

Type: Israel, Upper Galilee, at Dan, isolated from the citrus rust mite infesting grapefruit (Citrus xparadisi Macfad.), October 1996, sin. coll. (CBS 110052, holotype, preserved in a metabolically inactive state; isotype NRRL Y-27483).

Meira argovae Boekhout, Scorzetti, Gerson \& Sztejnb. ex Denchev \& T. Denchev, sp. nov. Index Fungorum number: IF 558273

For diagnosis see Boekhout et al., International Journal of Systematic and Evolutionary Microbiology 53: 1661, 2003.

Type: Israel, Ness Ziona, isolated from a carmine spider mite on leaves of castor bean (Ricinus communis L.), autumn 1996, sin. coll. (CBS 110053, holotype, preserved in a metabolically inactive state; isotype NRRL Y-27482).

[Meira argovae Boekhout, Scorzetti, Gerson \& Sztejnb., in Boekhout, Theelen, Houbraken, Robert, Scorzetti, Gafni, Gerson \& Sztejnberg, International Journal of Systematic and Evolutionary Microbiology 53: 1661, 2003 (nom. inval., Shenzhen Code, Art. 35.1, 40.7)]

Meira miltonrushii T.A. Rush \& Aime ex Denchev \& T. Denchev, sp. nov. Index Fungorum number: IF 558274

For description see Rush \& Aime, Antonie van Leeuwenhoek 103: 1101, 2013.

Type: U.S.A., Louisiana, East Baton Rouge Parish, Baton Rouge, Louisiana State University campus, isolated from a leaf surface of Magnolia grandiflora L., November 2009, M.C. Aime, no. 3882 (NRRL Y-48820, holotype, preserved in a metabolically inactive state; isotypes ATCC-MYA 4883, CBS 12591).

[Meira miltonrushii T.A. Rush \& Aime, Antonie van Leeuwenhoek 103: 1101, 2013 (nom. inval., Shenzhen Code, Art. 35.1)]

Meira nashicola F. Yasuda \& H. Otani ex Denchev \& T. Denchev, sp. nov. Index Fungorum number: IF 558275

For description see Yasuda et al., Mycoscience 47: 39, 2006.

Type: Japan, Honshu, Tottori Prefecture, Tohaku-cho, orchards, isolated from Japanese pear (Pyrus pyrifolia var. culta (Makino) Nakai) fruits with reddish stain, September 2001, sin. coll. (MAFF 230028, holotype, preserved in a metabolically inactive state; isotype CBS 117161).

[Meira nashicola F. Yasuda \& H. Otani, in Yasuda, Yamagishi, Akamatsu, Izawa, Kodama \& Otani, Mycoscience 47: 39, 2006 (nom. inval., Shenzhen Code, Art. 35.1)]

Meira nicotianae H.K. Wang \& F.C. Lin ex Denchev \& T. Denchev, sp. nov. Index Fungorum number: IF 558276 
For description see Cao et al., Phytotaxa 365: 176, 2018.

Type: China, Guizhou Province, planting farm of tobacco at Guiyang City, 26⒍ $2^{\prime} 83^{\prime \prime} \mathrm{N}$, $106^{\circ} 85^{\prime} 88^{\prime \prime} \mathrm{E}$, isolated from the rhizosphere of tobacco, sin. dat., sin. coll. (Mycological Collection of Zhejiang University, MCZU 1502, holotype, preserved in a metabolically inactive state; isotype CCTCC M2015704).

[Meira nicotianae H.K. Wang \& F.C. Lin, in Cao, Li, Zhao, Wang, Jeewon, Bhoyroo, Aruna, Lin \& Wang, Phytotaxa 365: 176, 2018 (nom. inval., Shenzhen Code, Art. 35.1)]

Meira siamensis Limtong, Polburee, Chamnanpa, Khunnamw. \& P. Limtong ex Denchev \& T. Denchev, sp. nov.

Index Fungorum number: IF 558277

For description see Limtong et al., International Journal of Systematic and Evolutionary Microbiology 67: 2420, 2017.

Type: Thailand, Ratchaburi Provincec, Mueang District, isolated from the phylloplane of vetiver grass (Chrysopogon zizanioides (L.) Roberty, syn. Vetiveria zizanioides (L.) Nash), 2012, sin. coll. (CBS 12860, holotype, preserved in a metabolically inactive state).

[Meira siamensis Limtong, Polburee, Chamnanpa, Khunnamw. \& P. Limtong, International Journal of Systematic and Evolutionary Microbiology 67: 2420, 2017 (nom. inval., Shenzhen Code, Art. 35.1)]

Acaromyces ingoldii (Boekhout et al. 2003) is not a validly published name, as two culture collections, in which the type is conserved, are specified: CBS 110050 and NRRL Y-27484.

[Acaromyces ingoldii Boekhout, Scorzetti, Gerson \& Sztejnb., in Boekhout, Theelen, Houbraken, Robert, Scorzetti, Gafni, Gerson \& Sztejnberg, International Journal of Systematic and Evolutionary Microbiology 53: 1662, 2003 (nom. inval., Shenzhen Code, Art. 40.7)]

Acaromyces ingoldii (Boekhout et al. 2003) is the type species of Acaromyces making this generic name invalidly published under Art. 40.1, see Arts 6.3, 12.1 (Shenzhen Code).

Acaromyces Boekhout, Scorzetti, Gerson \& Sztejnb. ex Denchev \& T. Denchev, gen. nov. Index Fungorum number: IF 558278

[non Acaromyces Lavie, L'Apiculteur 3: 44, 1950 (nom. inval., Shenzhen Code, Art. 39.1)]

For diagnosis see Boekhout et al., International Journal of Systematic and Evolutionary Microbiology 53: 1662, 2003.

Type species: Acaromyces ingoldii Boekhout, Scorzetti, Gerson \& Sztejnb. ex Denchev \& T. Denchev 
Acaromyces ingoldii Boekhout, Scorzetti, Gerson \& Sztejnb. ex Denchev \& T. Denchev, sp. nov.

Index Fungorum number: IF 558279

For diagnosis see Boekhout et al., International Journal of Systematic and Evolutionary Microbiology 53: 1662, 2003.

Type: Israel, south of the Sea of Galilee, isolated from the citrus rust mite on leaves of grapefruit (Citrus xparadisi Macfad.), 1995, sin. coll. (CBS 110050, holotype, preserved in a metabolically inactive state; isotype NRRL Y-27484).

\section{Validation of species names, invalidly published under Art. 40.7 of the ICN (Shenzhen Code), as more than one culture collection, in which the type is conserved, are specified}

Cystobasidium iriomotense Tanimura, Sugita \& M. Takash. ex Denchev \& T. Denchev, sp. nov.

Index Fungorum number: IF 558280

For description see Tanimura et al., PLoS ONE 13(9): e0202164, 9, 2018.

Type: Japan, Okinawa, Iriomote Island, Iriomote Ishigaki National Park, isolated from soil, November 2008, T. Sugita, s.n. (JCM 24594, holotype, preserved in a metabolically inactive state; isotype CBS 15015).

[Cystobasidium iriomotense Tanimura, Sugita \& M. Takash., in Tanimura, Sugita, Endoh, Ohkuma, Kishino, Ogawa, Shima \& Takashima, PLoS ONE 13(9): e0202164, 9, 2018 (nom. inval., Art. 40.7)]

Farysizyma Á. Fonseca was described as an anamorphic genus in the Ustilaginales to accommodate three ustilaginomycetous yeast species: F. itapuensis, F. setubalensis, and $F$. taiwaniana (Inácio et al. 2008), with a type species F. itapuensis Landell \& P. Valente. Farysizyma itapuensis (Inácio et al. 2008), however, is an invalidly published species name, as it was typified with two specimens (CBS 10428 and NRRL Y-48116), making the generic name Farysizyma invalidly published under Art. 40.1, see Arts 6.3, 12.1 (Shenzhen Code).

[Farysizyma itapuensis Landell \& P. Valente, in Inácio, Landell, Valente, Wang, Wang, Yang, Manson, Lachance, Rosa \& Fonseca, FEMS Yeast Research 8: 506, 2008 (nom. inval., Shenzhen Code, Art. 40.7)]

Thus, Farysizyma setubalensis and F. taiwaniana are not validly published names (Art. 35.1), as they were assigned to an invalidly published generic name. In the description of the genus Farysizyma (Inácio et al. 2008), it was noted: "Genus of epiphytic and anamorphic fungi that belongs to the Ustilaginales and is closely related to species of the genus Farysia". 
The phylogenetic position of the Farysizyma species in Farysia was demonstrated by Wang et al. (2015), who transferred Farysizyma itapuensis, F. setubalensis, and F. taiwaniana in Farysia, but their combinations are not validly published, as the 'basionyms' are not validly published names.

Farysia itapuensis Landell \& P. Valente ex Denchev \& T. Denchev, sp. nov. Index Fungorum number: IF 558281

For description see Inácio et al., FEMS Yeast Research 8: 506, 2008 (as 'Farysizyma itapuensis').

Type: Brazil, Rio Grande do Sul, Itapuã Park, Pedreira Beach, isolated from leaves of Vriesea friburgensis Mez (Bromeliaceae), sin. dat., sin. coll. (CBS 10428, holotype, preserved in a metabolically inactive state; isotype NRRL Y-48116).

Farysia setubalensis Á. Fonseca \& J. Inácio ex Denchev \& T. Denchev, sp. nov. Index Fungorum number: IF 558282

For description see Inácio et al., FEMS Yeast Research 8: 507, 2008 (as 'Farysizyma setubalensis').

Type: Portugal, Setúbal District, the Arrábida Natural Park, Fonte do Veado, isolated from the phylloplane of Cistus albidus L., sin. dat., sin. coll. (CBS 10241, holotype, preserved in a metabolically inactive state).

Farysia taiwaniana P.H. Wang, Yen T. Wang \& S.H. Yang ex Denchev \& T. Denchev, sp. nov.

Index Fungorum number: IF 558283

For description see Inácio et al., FEMS Yeast Research 8: 506, 2008 (as 'Farysizyma taiwaniana').

Type: Taiwan, NanJen-Shan Natural Reserve, approx. $22^{\circ} 40^{\prime} \mathrm{N}, 120^{\circ} 29^{\prime} \mathrm{E}$, isolated from the phylloplane of Daphniphyllum glaucescens subsp. oldhamii T.C. Huang (Daphniphyllaceae), sin. dat., sin. coll. (CBS 9927, holotype, preserved in a metabolically inactive state; isotype BCRC 23028).

Microsporomyces hainanensis F.R. Bai \& Yang Liu ex Denchev \& T. Denchev, sp. nov. Index Fungorum number: IF 558284

For description see Bai et al., Current Microbiology 73: 572, 2016.

Type: China, Hainan Province, the scientific research base of China National Hybrid Rice R\&D Center in Sanya City, $18^{\circ} 18^{\prime} 01^{\prime \prime} \mathrm{N}, 109^{\circ} 31^{\prime} 36^{\prime \prime} \mathrm{E}$, isolated from seeds of hybrid rice (Oryza sativa L.), sin. dat., sin. coll. (CICC 33066, holotype, preserved in a metabolically inactive state; isotype CBS 14092). 
[Microsporomyces hainanensis F.R. Bai \& Yang Liu, in Bai, Liu, Li, Yao, Li, Wang \& Cheng, Current Microbiology 73: 572, 2016 (nom. inval., Art. 40.7)]

Moniliella byzovii Thanh, Hien \& T.T. Thom ex Denchev \& T. Denchev, sp. nov. Index Fungorum number: IF 558285

For description see Thanh et al., International Journal of Systematic and Evolutionary Microbiology 63: 1195, 2013.

Type: Vietnam, Phan Thiet, Cape of Ke Ga, isolated from a flower of Ipomoea pes-caprae (L.) R. Br., 2012, sin. coll. (CBS 12757, holotype, preserved in a metabolically inactive state).

[Moniliella byzovii Thanh, Hien \& T.T. Thom, International Journal of Systematic and Evolutionary Microbiology 63: 1195, 2013 (nom. inval., Art. 40.7)]

Moniliella sojae Thanh, Hien, Yaguchi, J.P. Samp. \& Lachance ex Denchev \& T. Denchev, sp. nov.

Index Fungorum number: IF 558286

For description see Thanh et al., International Journal of Systematic and Evolutionary Microbiology 68: 1811, 2018.

Type: Vietnam, Hung Yen, My Hao, at Ban Yen Nhan, isolated from fermented soybean during traditional production of tuong (Vietnamese soy paste), sin. dat., sin. coll. (CBS 126448, holotype, preserved in a metabolically inactive state; isotype NRRL Y-48680).

[Moniliella sojae Thanh, Hien, Yaguchi, J.P. Samp. \& Lachance, International Journal of Systematic and Evolutionary Microbiology 68: 1811, 2018 (nom. inval., Art. 40.7)]

Occultifur kilbournensis Kurtzman \& Robnett ex Denchev \& T. Denchev, sp. nov. Index Fungorum number: IF 558287

For description see Kurtzman \& Robnett, Antonie van Leeuwenhoek 107: 1325, 2015. Type: U.S.A., Illinois, Kilbourne, an maize field, isolated from maize plants and from surrounding soil, April 2012, sin. coll. (NRRL Y-63695, holotype, preserved in a metabolically inactive state; isotype CBS 13982).

[Occultifur kilbournensis Kurtzman \& Robnett, Antonie van Leeuwenhoek 107: 1325, 2015 (nom. inval., Art. 40.7)]

Occultifur tropicalis Khunnamw., Suruss., Jindam., J.R.A. Ribeiro, Hagler \& Limtong ex Denchev \& T. Denchev, sp. nov.

Index Fungorum number: IF 558288

For description see Khunnamwong et al., International Journal of Systematic and Evolutionary Microbiology 65: 1580, 2015. 
Type: Thailand, Lopburi Province, Chai Badan District, $15^{\circ} 11^{\prime} 22^{\prime \prime} \mathrm{N}, 101^{\circ} 7^{\prime} 37^{\prime \prime}$ E, isolated from the tissue of a sugar cane (Saccharum officinarum L.) leaf, 2 Mar 2012, sin. coll. (BCC 61184, holotype, preserved in a metabolically inactive state; isotypes CBS 13389, NBRC 109696).

[Occultifur tropicalis Khunnamw., Suruss., Jindam., J.R.A. Ribeiro, Hagler \& Limtong, International Journal of Systematic and Evolutionary Microbiology 65: 1580, 2015 (nom. inval., Art. 40.7)]

Rhodotorula taiwanensis F.L. Lee \& C.H. Huang ex Denchev \& T. Denchev, sp. nov. Index Fungorum number: IF 558289

For diagnosis see Huang et al., Antonie van Leeuwenhoek 99: 300, 2011.

Type: Taiwan, near Kaohsiung, isolated from Artemisia argyi H. Lév. \& Vaniot, 18 Mar 2007, sine coll. (BCRC 23118, holotype, preserved in a metabolically inactive state; isotype CBS 11729).

[Rhodotorula taiwanensis F.L. Lee \& C.H. Huang, in Huang, Lee, Tien \& Hsieh, Antonie van Leeuwenhoek 99: 300, 2011 (nom. inval., Art. 40.7)]

\section{Validation of the names Glaciozyma littorale and Rhodotorula dairenensis}

Glaciozyma litorale, proposed by Kachalkin (2014), is not a validly published name (Shenzhen Code, Art. 35.1), as it was assigned to an invalidly published generic name, Glaciozyma, based on G. antarctica (Fell, Statzell, I.L. Hunter \& Phaff) Turchetti et al. (Turchetti et al. 2011:579). The combination Glaciozyma antarctica was published without fulfilment of the relevant requirements of the Code (Art. 41.5, see Note 1). The names Glaciozyma and G. antarctica were recently validated in Li et al. (2020: 133-134).

Glaciozyma litoralis Kachalkin ex Denchev \& T. Denchev, sp. nov.

Index Fungorum number: IF 558290

For description see Kachalkin, Antonie van Leeuwenhoek 105: 1082, 2014.

Type: Russia, isolated from silty-sandy substrate of intertidal zone of the White Sea, near the White Sea Biological Station 'Kartesh', June 2011, A.V. Kachalkin (CBS 12957, holotype, preserved in a metabolically inactive state; isotypes KBP 4246, VKPM Y-3850, PYCC 6252, DSM 28204).

[Glaciozyma litorale Kachalkin, Antonie van Leeuwenhoek 105: 1082, 2014 (nom. inval., Shenzhen Code, Art. 35.1)]

Rhodotorula dairenensis (T. Haseg. \& I. Banno) Denchev \& T. Denchev, comb. et st. nov. Index Fungorum number: IF 558291 
Basionym: Rhodotorula glutinis var. dairenensisT. Haseg. \& I. Banno, Journal of Fermentation Technology 36(10): 405, 1958.

[Rhodotorula dairenensis (T. Haseg. \& I. Banno) Fell, J.P. Samp. \& Gadanho, in Gadanho \& Sampaio, FEMS Yeast Research 2: 56, 2002 (the basionym is not indicated with a full and direct reference - nom. inval., Shenzhen Code, Art. 41.5)]

\section{ORCID}

Cvetomir M. Denchev, https://orcid.org/0000-0001-6301-1629

Teodor T. Denchev, https://orcid.org/0000-0002-7242-3307

\section{References}

Bai, F., Liu, Y., Li, N., Yao, S., Li, N., Wang, W. \& Cheng, C. 2016. Microsporomyces hainanensis sp. nov., isolated from hybrid rice (Oryza sativa L.) Seeds. - Current Microbiology 73: 569-573. https://doi.org/10.1007/s00284-016-1095-8

Boekhout, T., Theelen, B., Houbraken, J., Robert, V., Scorzetti, G., Gafni, A., Gerson, U. \& Sztejnberg, A. 2003. Novel anamorphic mite-associated fungi belonging to the Ustilaginomycetes: Meira geulakonigii gen. nov., sp. nov., Meira argovae sp. nov. and Acaromyces ingoldii gen. nov., sp. nov. - International Journal of Systematic and Evolutionary Microbiology 53: 1655-1664. https://doi.org/10.1099/ijs.0.02434-0

Cao, Y., Li, P.-D., Zhao, J., Wang, H.-K., Jeewon, R., Bhoyroo, V., Aruna, B., Lin, F.-C. \& Wang, Q. 2018. Morph-molecular characterization of Meira nicotianae sp. nov., a novel basidiomycetous, anamorphic yeast-like fungus associated with growth improvement in tobacco plant. - Phytotaxa 365: 169-181. https://doi.org/10.11646/phytotaxa.365.2.4

Gadanho, M. \& Sampaio, J.P. 2002. Polyphasic taxonomy of the basidiomycetous yeast genus Rhodotorula: Rh. glutinis sensu stricto and Rh. dairenensis comb. nov. - FEMS Yeast Research 2: 47-58. https://doi.org/10.1111/j.1567-1364.2002.tb00068.x

Huang, C.-H., Lee, F.-L., Tien, C.-J. \& Hsieh, P.-W. 2011. Rhodotorula taiwanensis sp. nov., a novel yeast species from a plant in Taiwan. - Antonie van Leeuwenhoek 99: 297-302. https://doi.org/10.1007/s10482-010-9489-2

Inácio, J., Landell, M.F., Valente, P., Wang, P.-H., Wang, Y.-T., Yang, S.-H., Manson, J.S., Lachance, M.A., Rosa, C.A. \& Fonseca, Á. 2008. Farysizyma gen. nov., an anamorphic genus in the Ustilaginales to accommodate three novel epiphytic basidiomycetous yeast species from America, Europe and Asia. FEMS Yeast Research 8: 499-508. https://doi.org/10.1111/j.1567-1364.2008.00377.x

Kachalkin, A.V. 2014. Yeasts of the White Sea intertidal zone and description of Glaciozyma litorale sp. nov. - Antonie van Leeuwenhoek 105: 1073-1083. https://doi.org/10.1007/s10482-014-0165-9

Khunnamwong, P., Surussawadee, J., Jindamorakot, S., Ribeiro, J.R.A., Hagler, A.N. \& Limtong, S. 2015. Occultifur tropicalis f.a., sp. nov., a novel cystobasidiomycetous yeast species isolated from tropical regions. - International Journal of Systematic and Evolutionary Microbiology 65: 1578-1582. https://doi.org/10.1099/ijs.0.000140 
Kurtzman, C.P. \& Robnett, C.J. 2015. Occultifur kilbournensis f.a. sp. nov., a new member of the Cystobasidiales associated with maize (Zea mays) cultivation. - Antonie van Leeuwenhoek 107: 1323-1329.

https://doi.org/10.1007/s10482-015-0427-1

Li, A.-H., Yuan, F.-X., Groenewald, M., Bensch, K., Yurkov, A.M., Li, K., Han, P.-J., Guo, L.-D., Aime, Sampaio, J.P., Jindamorakot, S., Turchetti, B., Inacio, J., Fungsin, B., Wang, Q.-M. \& Bai, F.-Y. 2020. Diversity and phylogeny of basidiomycetous yeasts from plant leaves and soil: Proposal of two new orders, three new families, eight new genera and one hundred and seven new species. - Studies in Mycology 96: 17-140.

https://doi.org/10.1016/j.simyco.2020.01.002

Limtong, S., Polburee, P., Chamnanpa, T., Khunnamwong, P. \& Limtong, P. 2017. Meira siamensis sp. nov., a novel anamorphic ustilaginomycetous yeast species isolated from the vetiver grass phylloplane. International Journal of Systematic and Evolutionary Microbiology 67: 2418-2422. https://doi.org/10.1099/ijsem.0.001969

Rush, T.A. \& Aime, M.C. 2013. The genus Meira: phylogenetic placement and description of a new species. - Antonie van Leeuwenhoek 103: 1097-1106. https://doi.org/10.1007/s10482-013-9889-1

Tanimura, A., Sugita, T., Endoh, R., Ohkuma, M., Kishino, S., Ogawa, J., Shima, J. \& Takashima, M. 2018. Lipid production via simultaneous conversion of glucose and xylose by a novel yeast, Cystobasidium iriomotense. - PLoS ONE 13(9): e0202164.

https://doi.org/10.1371/journal.pone.0202164

Thanh, V.N., Hien, D.D. \& Thom, T.T. 2013. Moniliella byzovii sp. nov., a chlamydospore-forming black yeast isolated from flowers. - International Journal of Systematic and Evolutionary Microbiology 63: 1192-1196.

https://doi.org/10.1099/ijs.0.049767-0

Thanh, V.N., Hien, D.D., Yaguchi, T., Sampaio, J.P. \& Lachance, M.-A. 2018. Moniliella sojae sp. nov., a species of black yeasts isolated from Vietnamese soy paste (tuong), and reassignment of Moniliella suaveolens strains to Moniliella pyrgileucina sp. nov., Moniliella casei sp. nov. and Moniliella macrospora emend. comb. nov. - International Journal of Systematic and Evolutionary Microbiology 68: 1806-1814. https://doi.org/10.1099/ijsem.0.002690

Turchetti, B., Thomas Hall, S.R., Connell, L.B., Branda, E., Buzzini, P., Theelen, B., Müller, W.H. \& Boekhout, T. 2011. Psychrophilic yeasts from Antarctica and European glaciers: description of Glaciozyma gen. nov., Glaciozyma martinii sp. nov. and Glaciozyma watsonii sp. nov. - Extremophiles 15: 573-586.

https://doi.org/10.1007/s00792-011-0388-x

Wang, Q.-M., Begerow, D., Groenewald, M., Liu, X.-Z., Theelen, B., Bai, F.-Y. \& Boekhout, T. 2015. Multigene phylogeny and taxonomic revision of yeasts and related fungi in the Ustilaginomycotina. Studies in Mycology 81: 55-83.

https://doi.org/10.1016/j.simyco.2015.10.004

Yasuda, F., Yamagishi, D., Akamatsu, H., Izawa, H., Kodama, M. \& Otani, H. 2006. Meira nashicola sp. nov., a novel basidiomycetous, anamorphic yeastlike fungus isolated from Japanese pear fruit with reddish stain. - Mycoscience 47: 36-40.

https://doi.org/10.1007/S10267-005-0266-4 